\title{
The Functions of the English Vice and Dutch Sinnekens: A Comparison
}

Two markedly similar conventional dramatic types emerged in the sixteenth century: the Vice in the English moral interludes and the sinnekens in the Dutch spelen van sinne. ${ }^{1}$ These dramatic types have been the subject of valuable research, most notably by Bernard Spivack and W.M.H. Hummelen. ${ }^{2}$ Yet remarkably, although both traditions gave rise to these negative conceptual characters who were the theatrical stars of their respective traditions, little research has focused on the similarities and differences between the two dramatic types. ${ }^{3}$ The claims concerning possible Dutch influence on English drama, moreover, have never yet been investigated in connection with these similar dramatic conventions. ${ }^{4}$ Hummelen offers a passing comparison of the sinnekens with the English vices in one article, but he merely claims that the English vices are less stereotypical than the sinnekens. ${ }^{5}$ Finally, Peter Happé and Wim Hüsken 'set out the basis of a comparative study of the Sinnekens ... in late medieval and early Renaissance Dutch drama, and the Vice of the English interludes' but this study has so far not led to more research. ${ }^{6}$ In this article I shall continue the research of especially Happé and Hüsken by presenting a synchronic comparison of these two dramatic types in terms of their functions within the plays. I argue that the Vice and sinnekens are indeed markedly similar yet also substantially different and that they certainly do not support, and if anything argue against, Dutch influence on English drama in the sixteenth-century and, for that matter, vice versa.

The scope of this article does not allow for a detailed introduction of the two dramatic traditions but highlighting a few salient features will allow the reader better to contextualize the following analysis. First, some differences between the two dramatic types are obvious. For example, English drama allows one Vice per play, although he often has minor vices as side-kicks, whereas the sinnekens occur nearly always as a pair and have no real side-kicks. The Vice figure probably emerged in England during 
the 1530s but the heyday of the Vice roughly spans the period from the 1550s until the 1580s; the first surviving example of an undisputed Vice figure being labelled as such is Avarice in Respublica (performed in 1553). ${ }^{7}$ The playwrights and scribes of the Low Countries only started using the word sinnekens regularly in the 1550s but the earliest credible examples of sinnekens date from c 1500; the type therefore seems to develop considerably earlier than the English Vice.

Most English moral interludes were written for and performed by childactors or small, often travelling, troupes of (semi-)professional actors. The surviving plays frequently demonstrate clear links with London, and with the higher echelons of society, and many were presumably written with an in-door hall performance in mind. ${ }^{8}$ The so-called rhetoricians (rederijkers) formed the most important literary movement in the Low Countries. These rhetoricians, who gathered in chambers of rhetoric (rederijkerskamers) to write and recite poetry, and to write and perform plays, were almost exclusively male and mainly middle-class artisans and merchants. They were emphatically and proudly amateur and seem to have held professional actors in abhorrence. ${ }^{9}$ The rhetoricians were fiercely competitive in upholding the honour and reputation of their chamber and their city or village and frequently organized literary competitions to exhibit their skills. Various prizes were to be won at these competitions, not only for best play, but also in other categories such as grandest entrance into the city, best serious actor, best comic actor, and best fireworks. ${ }^{10}$

These differences in the organization of actors and playwrights did affect the drama in the two countries. For example, the divergence between more outspoken English plays and more moderate Dutch plays can, at least partly, be attributed to the difference in intended performance. As Walker has convincingly shown, contemporaries considered many moral interludes to be tools for persuasion within the world of Tudor politics and used them to highlight and address specific current affairs. As a result, despite their more general moral and religious overtones - which presumably became of utmost importance for later spectators and readers - most of the English interludes had a carefully crafted message intended for the understanding of the lord and members of the household. ${ }^{11}$ The rhetoricians' spelen van sinne, though most certainly regarded as tools for education, were intended for public outdoor performance and their messages were usually much more general than those of the English plays. The rhetoricians were concerned with educating both their members and their audiences, as well as with propriety and good 
manners, as becomes clear from their founding charters and regulations. For instance, a charter from Aalst from 1539 stresses that rhetoric serves to 'receive and teach the way of sanctity, and the sense of reasonable intellect' and the Twe-Spraack vande Nederduitsche letterkunst [Dialogue of LowDutch Literature], a handbook published by the Amsterdam chamber De Eglentier [The Eglantine] in 1584, claims concerning 'the chambers' original purpose: it will be seen that they were instituted as schools using the country's common language, for all art-loving adult persons to practise knowledge delightful and useful to the country.' 12 This didactic emphasis explains the relatively restrained characterization of the sinnekens in the spelen van sinne, and indeed of the spelen van sinne at large. Conversely, in England, professionals often performed the moral interludes, and suffused their negative characters, especially the Vice, with every possible strategy to entertain the audience's goodwill and to display the actors' skills. The differences in the use of the Vice in the moral interludes and the sinnekens in the Dutch spelen van sinne indicate the different theatrical cultures of the English and Dutch playwrights.

The corpus I use here for the analysis of the Vice and sinnekens cannot claim to be exhaustive; compare, for instance, Hummelen's study of the sinnekens, based on 200 plays. ${ }^{13}$ Instead I have tried to juggle the somewhat contradictory criteria of representativeness (in so far as that is possible given that presumably few plays have survived) and close reading. The aim behind the selection was to have plays which cover the period when the Vice and sinnekens mainly appeared (made more difficult by the fact that so many plays are not precisely datable), a variety of genres (eg, classical, biblical), and topics (eg. social ills, religious conflict). I hope that I have used a sufficient number of plays to give a fair idea of the general character of the Vice and sinnekens, so that I can persuasively compare and contrast the two dramatic traditions and their representatives of evil. See the appendix for the list of the texts analyzed and the short titles used.

A stage character can have various functions which are usually intricately intertwined. Admittedly separating them is rather artificial as they often operate at the same time and are dependent on one another. Nevertheless, an attempt to identify some of the most important functions of the Vice and sinnekens and assess to what extent they were emphasized is worthwhile, as this effort enables us to perceive why and how the playwrights used these characters. In my opinion, five functions are of special interest: 
- the dramatic function which relates to the role of a character in the plot (such as tempter or victim);

- the technical function which covers the sayings and deeds that help to structure the play, to clarify the plot, and to pace the development of the plot;

- the didactic function which relates to the character's expressed insight into the morality of the actions and characters onstage and/or their real-life counterparts;

- the comic function which relates to the playwright's use of a character to provide entertainment;

- the conceptual function which relates to the appropriateness of the conceptual name with regard to the role and characterization of the character, and also covers the extent to which the character is represented as an immortal, unchangeable personification or as a mortal, changeable type.

All five are present in both the Dutch and English dramatic traditions, but they are not always emphasized to the same degree. In terms of function within the play, it seems logical to assume that the negative conceptual characters mainly embodied the negative influence over the protagonist that set the narrative of the play going or else enabled a narrative of psychomachia. The various functions of the Vice and sinnekens suggest, however, that their role in the plot is not as important as some of the other tasks which they perform within the plays. As will become clear in the analysis of the different functions, the Vice and sinnekens were not simply inherent to the narratives of the plays, but that the playwrights used these characters for specifically theatrical purposes.

\section{Dramatic Function}

The most salient rationale behind the use of the Vice and sinnekens is not their dramatic function as tempter of a virtuous protagonist; on the contrary, their dramatic function is often circumscribed. When the protagonist is from the outset less than a paradigm of virtue, the influence of the Vice and sinnekens merely furthers the demise of the protagonist. The protagonist need not be a confirmed sinner - in the Dutch so-called romanticmythological plays the victim is merely in love - but the sinnekens rarely 
corrupt a virtuous or wholly innocent protagonist. ${ }^{14}$ As a result the sinnekens are usually not so much tempter figures as exacerbators of evil. ${ }^{15}$ Similarly, the beginnings of English plays often present the protagonist as less than a paradigm of virtue. Some English protagonists are so far advanced on the downward moral spiral that the Vice has very little left to do. More so than the sinnekens, however, the Vice is quite capable of leading good protagonists down the wrong path. ${ }^{16}$

Yet despite their somewhat restricted dramatic function on stage, the Vice and sinnekens do claim to have much sway over life offstage. The sinnekens often boast of a general and, less frequently, eternal influence above and beyond their power and effect in the play. The claim of a more wide-spread effect outside the plot is present in most plays and specifically relates to the didactic message of the play. ${ }^{17}$ For example, in the mercatorial Sanders Welvaren the sinnekens boast of their influence over business transactions (as in 76-110). The eternal aspect is not as frequent but it is a common element in what Hummelen calls the blame-motif, in which the sinnekens blame one another for all the evils of Christian history. ${ }^{18}$ The term 'blame-motif', however, is too one-sided as the sinnekens also brag about their eternal influence:

Dedick lucifer niet den hemel ruijmen snel? ...

Ick heb doer Euam, thaerder onvromen spijtich, Adam ghegheuen van God het verboden fruijt. Ick brocht Abel om van Caijm te doden vuijt.

(Cristenkercke 339-45)

[Did I not make Lucifer quickly vacate heaven? ...

I have through Eve, to her pitiable disadvantage, given Adam God's forbidden fruit.

I brought Abel to be killed by Cain.]

These boasts and charges of eternal influence were popular theatrical methods, mostly as part of the blame-and/or-boast-motif which allowed the playwrights to combine didacticism with comedy. (Here we already encounter an instance where a sharp distinction between the different functions breaks down.) Although the Vice occasionally makes a passing reference to his eternal influence, and, more frequently, to his general influence, neither became 
a set feature. But sometimes the claim of general influence embroiders a misogynistic comment and develops into interaction with the audience, as when the Vice in Horestes specifically associates himself with women:

Nay, I knowe their quallytes, the lesse is my care, As well as they do knowe Revengys operation.

Ye, faull to it, good wyves, and do them not spare!

Nay, Ille helpe you forward, yf you lacke but perswacion.

(Horestes 1087-9)

In a similar vein, Inclination claims:

the might of the earth I doe subdue

tush, if you will giue me leaue yle tell ye howe, ...

But then these gentlewomen will be angry.

(Trial 125-9)

The didactic element is minimal here; instead the claim of influence builds up the theatricality of the Vice, as it allows for moments of comedy, and the metatheatricality of the Vice, as it breaches the division between play and reality. The sinnekens' claims of general or eternal influence undoubtedly have an element of comedy and metatheatricality too, but they are mainly used to strengthen the dramatic and didactic load of the sinnekens.

Overall, while clearly the dramatic role of the Vice and the sinnekens is relatively unified in that they are always tempters or exacerbators of evil, just as clearly the enactment of the dramatic function was not of utmost importance for the playwrights. The addition of sinnekens and Vice figures to pre-existing stories which were originally without negative tempter figures, such as Mars en Venus and Cambises, where the Vice's and sinnekens' influence over the protagonists and plot developments is often largely superfluous, indicates that the dramatic function was not the primary reason for having these characters in a play. Instead of focusing on the role of these characters within the plot, the playwrights were keen to explore the didactic, comic, and even metatheatrical possibilities of the supposed evil influence of the Vice and the sinnekens.

If the dramatic function was not the main reason for using these negative characters, what was? The answer is, I think, not the same for the two traditions; in fact, it is not the same for different plays within either of the 
dramatic traditions and we must bear in mind the variations within the traditions. But, generally speaking, the sinnekens have a much more important technical, didactic, and even conceptual load than the Vice, whereas the Vice's main function seems to be to add an element of comedy and metatheatricality to the play.

\section{Technical Function}

The technical function is often a characteristic and important element of the Dutch sinnekens. They are frequently used for such obviously technical tasks as serving the protagonist in the tavern or banquet scenes and effecting a change of the protagonist's costume to highlight his fall into sin, as in Caprijcke (204-16, 256-65) and sMenschen Sin (288-320, 690-7 and the stage direction after 697). Furthermore, they frequently narrate essential background information, introduce characters, elucidate the action on stage, and indicate changes in time or place. The sinnekens in Mars en Venus, for instance, are almost always used to describe on- or offstage action; by far their most characteristic function is technical. In Wellustige Mensch Gratie Goods [God's Grace], who silently follows the protagonist around for most of the play, is identified by the sinnekens (22); without this identification she would presumably have been unrecognizable for the audience. The sinnekens also stress that the protagonist is oblivious to her silent presence (24-5), which allows the audience to arrive at the correct interpretation of the protagonist's lack of interaction with his silent shadow. In both Pyramus and Thisbe plays the sinnekens provide essential background information: they introduce the characters and the plot (eg, Antwerp Pyramus ende Thisbe 101-64), indicate the passing of time and the change of place (as when they announce daybreak and Thisbe's arrival at Ninus's grave in Haarlem Piramus en Thisbe 330-43), and narrate and elucidate on- and offstage action (for instance, they describe the arrival of the lion and how he gnaws and bloodies Thisbe's head-gear in Antwerp Pyramus ende Thisbe 1234-54). Clearly, the sinnekens were conventionally used to help structure the plays and, given this fact, one can imagine that their presence in a play brought considerable practical advantages to the playwright. How to stage a sex scene? Let a pair of voyeuristic sinnekens peek through a window and comment on the developments (as happens in Mars en Venus 795-847). How to stage night? Let the sinnekens remark on nightfall (as happens in the Antwerp Pyramus ende Thisbe 1144, 1156). 
Sometimes the technical load of the Vice is relatively pronounced. For instance, in Cambises Ambidexter introduces the plot and characters and narrates offstage events, as when he promises the destruction of the judge Sisamnes (155-6), introduces Cambises's brother (621), and describes the wedding feast (938-50). But normally the Vice has a limited technical function. The Vice in Horestes introduces the main theme of the play, namely Horestes's desire for revenge (13-14), but then Rusticus elaborates on this theme in greater detail (22-9). Later in the play the Vice also mentions the fact that Horestes has married (1046), but as this marriage has been discussed in the scene preceding the Vice's revelation (1016-33) and as Hermione, the bride, is one of the characters in the scene following it, we can hardly consider this revelation to consist of important background information. Another point to note concerning the technical function of the Vice is that he often appears as a human agent, involved in the action with a human awareness and knowledge of the plot and its implications. For example, Ambidexter does not claim to know the future or the ultimate fate of Cambises. He is merely willing to lay a wager concerning the future: 'Heare ye? I wil lay twentie thousand pound: / That the king him self dooth dye by some wound' (Cambises 1149-50).

Clearly, then, the English playwrights did not develop the technical function of the Vice to any great degree, whereas the Dutch playwrights skilfully and purposefully used the sinnekens to help structure the play, clarify the plot, and pace and locate the development of the plot. We can relate this difference, at least partly, to the fact that the Dutch sinnekens operate in pairs, a dramaturgical choice which makes it possible for them to convey information without breaking the 'realism' of the dramatic world as they need only address each other. Yet, as the Vice normally thrives on interaction with the audience, a desire to maintain the 'realism' of the dramatic world cannot wholly explain this difference. Apparently the sinnekens' fairly consistent portrayal as personifications of concepts (see section on Conceptual Function) and their ability to stand back from the action in order to comment on it sub specie aeternitatis also furthered their role as informers and consequently their technical function. ${ }^{19}$ Conversely the Vice's more limited conceptual load (see section on Conceptual Function) and characterization in more human terms brought his technical function on a par with that of the other human characters. In any case, unlike the Dutch playwrights, sinnekens, the English playwrights did not use their theatrical star for practical, structural reasons. 


\section{Didactic Function}

Although some of the Vice figures and sinnekens do occasionally indulge in an emphatic display of didacticism where they lecture a protagonist or audience directly, on the whole their didactic function is not so explicit, relying mostly on their name and evident immorality. Their didactic function is therefore rather similar.

The Vice and sinnekens with names such as Envy and Blijnde Begeerte [Blind Desire] necessarily possess an element of didacticism and given the didactic and conceptual importance of the names of these characters, not surprisingly, their names often emphatically thrust to the fore. Thus many of the sinnekens' scenes apart open with a 'call-to-stage', a device emphasizing the significance of their names, as in

QUADEN WILle Hau! Zinnelick Ingheven, talder liefste maechskin myn! SINNELICK INGHEVEN Wat schuulter, Quaden Wille mynen goeden compeyn reyn?

(Zoone 2.1-2)

[evil will Ho! Sensual Inclination, my very dearest kinsman! SENSUAL INCLINATION What is the matter, Evil Will, my good, pure companion?]

The sinnekens, moreover, regularly and repeatedly identify one another as in the following dialogue:

FRAUDELIC SCHIJN Hoe heet ghi maech? BEDRIEGHELIC WAEN Bedriechelic waen.

FRAUDELIC SCHIJN En ic ben fraudelic schijn ghenaemt

Ha bedrieghelic waen! BEDRIEGHELIC WAEN Ha fraudelic schijn!

(Antwerp Pyramus en Thisbe 75-81)

[FRAUDULENT IMPRESSION What are you called, kinsman? deceptive appearance Deceptive Appearance.

FRAUDULENT IMPRESSION And I am called Fraudulent Impression. 


\author{
-.. \\ Ha, Deceptive Appearance! \\ DECEPTIVE APPEARANCE Ha, Fraudulent Impression!]
}

Similarly, in the moral interludes the Vice often introduces himself, as in 'Courage contagious / Or courage contrarious, / That is my name' (Tide 37-9), or is named by other characters, as when the Devil calls 'oh my child Hypocrisy, where art thou?' (Lusty Juventus 357). In fact, the name is of such importance that a climax sometimes builds up before the Vice's name is revealed. Thus in Grissell the Vice claims to have lost his name:

My name, body o God, I am cleane nipt in the head,

My name, whye wher is it, what is it fled

A name quoth you?

So, so, so, lo, now seeke all about,

Nowe searche euerie hole, wythin and without,

I am cauled Polliticke perswasion in deed.

(Grissell 95-110)

And here a difference between the English and Dutch tradition emerges. Losing or forgetting one's name is a useful strategy for implanting that name firmly in the mind of the spectator, and therefore has a didactic side. But what is most noticeable in such instances of the Vice forgetting his name in the English plays is the comedy (and the metatheatricality if the Vice searches for his name in the audience's space). Another more standard way of highlighting the importance of the name of the Vice and minor vices is the use of aliases. In Respublica, for instance, Avarice becomes Policy; Insolence, Authority; Oppression, Reformation; and Adulation, Honesty. These changes of name, while emphasizing the deceptive and immoral nature of the Vice and vices, often give rise to comical and metatheatrical moments. In Respublica one of the minor vices, Adulation, repeatedly forgets the aliases:

AVARICE Well then, for this time thy name shall be Honesty.

adulation I thank you, Avarice. Honesty, Honesty.

AVARICE Avarice, ye whoreson? Policy, I tell thee!

adulation How say you, Insolence? I am now Honesty. 
AVARICE We shall at length have a knave of you, Honesty.

Said I not he should be called Monsieur Authority?

adulation Oh friend Oppression, Honesty, Honesty!

AVARICE Oppression? Ha, Is the devil in thy brain?

Take heed, or in faith ye are Flattery again.

Policy, Reformation, Authority.

adulation Hypocrisy, Diffamation, Authority! (Respublica 366-77)

And so it goes on. Metatheatrical humour occurs when Covetousness in Enough claims to be distracted from his search for good aliases by members of the audience $(478,483)$. Exchanges of this kind in the English plays emphasize the names of the vices and the Vices and have a clear didactic element to them, but are at least as, if not more, noteworthy for their entertainment values. Although by no means as frequently, the sinnekens also occasionally change their names: in Redelickheijt they decide to leave out the first part of their names and consequently they appear as Lust [Lust] and Begeerte [Desire]. This truncation is no mere linguistic omission, as they physically cover the first word of their name tags. ${ }^{20}$

BLIJNDE BEGEERTE Ons namen sullen wij eensdeels oick verdoven wel om niet te bedrooven tspel ... teerste woordeken sullen wij Laeten achter blijven $\cdots$

ONBEHOORLIJCKE LUST Ick sal Dan Lust heeten BLIJNDE BEGEERTE En ick begeerte siet (Redelickheijt 317-24)

[BLIND DESIRE We shall also partially soften our names

In order not to ruin the game...

We shall omit the first word ...

IMPROPER LUST I shall then be called Lust.

BLIND DESIRE And I Desire, look!]

However, this changing of names in the Dutch play, although undoubtedly entertaining to a degree, is not as theatrical as the equivalent scenes in the English plays.

Explicit boasts of immorality and immoral influence, while clearly didactic, again present moments with comic and metatheatrical potential. The 
plays do not always exploit this potential to the full. They may subdue the metatheatricality and comedy, as in Hypocrisy's boasts to the Devil that

\author{
I have been busied since the world began \\ To graff thy laws in the heart of man, \\ Where they ought to be refused; \\ And I have so mingled God's commandments \\ With vain zeals and blind intents, \\ That they be greatly abused. \\ (Lusty Juventus 396-401)
}

Nor do we encounter much (meta)theatricality when Geveijnsde Hovaerdij [Fake Pride] in Becooringe exclaims 'evil Eternal Hatred,/ your false advice is everywhere' and when one Vice introduces himself with 'my very true unchristian name is Avarice' (Respublica 13). ${ }^{21}$

More comedy and audience interaction occur when the Vice and sinnekens teach through inversion; that is, they advise the audience to behave in blatantly immoral or sinful ways. For example, Geveijnsde Hovaerdij [Fake Pride] recommends 'let yourself be served by the sweat of the poor; /do not mind their complaints. ${ }^{22}$ This inversion also emphasizes the evil nature of the Vice and sinnekens and reinforces the didactic message, but we should not overlook the comic and metatheatrical aspects of these instances. The latter two were especially important in the English tradition where the most popular variety of inverted didacticism is the advice given to pickpockets in the audience, as in 'good cousin Cutpurse, if you be in place / I beseech you now your business to ply' (Tide 971-2) - here the didactic message is negligible in comparison with its comedy and metatheatricality.

We have already seen that their criticism of contemporary reality could reinforce the dramatic function of the Vice and especially of the sinnekens. In addition to the obvious didacticism here, by linking the play with reality the sinnekens and Vice necessarily play with the boundaries between the theatrical space and world of the play and the physical space and ordinary world of the spectators. In the Dutch plays we often find condemnation of contemporary mores, as in the tirade against supposed flaws in the lifestyle of the 1540s:

MANIER So pompös, elc mach hem wel vresen,

Verstaet wel desen dier comt in huijs gestegen.

GEWOONTE Hûe soe? 
MANIER Maer men mûet eerst die vûeten vegen,

Of onverswegen en blijfter niet een quaet woort.

(sMenschen $\operatorname{Sin} 760-3)$

[MANNER So pompous that all should be afraid

who want to enter a house - understand it well.

CUSTOM How is that?

MANNER Because one has to wipe one's feet first!

And if you do not, not one bad word will remain unsaid.]

They also moan, amongst other things, about people wearing costly clothes, having their portraits painted, having antique-style beds, and taking four or five lovers $(745-58,768-72)$. Despite an undeniable element of comedy and metatheatricality here, didacticism seems to be the most important effect of this speech. The references to supposed contemporary ills in the English plays, on the other hand, appear more overtly to enhance the theatrical and metatheatrical appeal of the Vice. For example, Courage implies, in his interaction with the audience, that (young) women are loath to be virgins: 'How say you, my virgins every one, / Is it not a sin to lie alone? / When 12 years of age is gone / I dare say you think so every one' (Tide 872-5). Haphazard's criticism of legal matters is enshrined in such verbal gymnastics as to make the message appear subordinate to the delivery:

And Iudgement iudge Iustice to have a reward For iudging still iustly, but all is now marde, / For giftes they are geven wher iudgement is none. /

Thus Iudgement and Iustice a wronge way hath gone.

(Apius and Virginia 444-7)

By and large, then, the Vice and the sinnekens share a relatively similar didactic function in that it is not momentous but mainly indirect and implicit, contained in their names and immoral behaviour or advice. The most interesting aspect of the didactic function of the Vice, however, is that English playwrights often seize it as an opportunity for making these characters more comical and metatheatrical. This dramaturgical choice somewhat lessens the didactic importance of the Vice, certainly in comparison with the sinnekens whose didactic function is not exploited for comic or metatheatrical effect to any great degree. 


\section{Comic Function}

As my argument makes clear to this point, the Vice and sinnekens have a comic function and this function is much more developed for the Vice than for its Dutch counterpart; I have already given examples.

The comic aspect of the sinnekens, although ubiquitous, is generally not extensively developed, even though they are normally the only or by far the most comical characters. ${ }^{23}$ Comedy nearly always has a further didactic purpose in these plays. For instance, in Wellustige Mensch the disagreement of the sinnekens Quaet Gelove [Evil Faith] and Vleijschelijcke Sin [Carnal Desire] about which of them is more evil (147-253) is comical to some extent, but here laughter has close links to awe and fear. The sharp contrast between the elevated speeches of the sinful protagonists and the sarcastic comments of the sinnekens creates moments of comedy in Cristenkercke but also highlights the protagonists' sinfulness:

VPRECHT SIMPEL GHELOUEN Dien dronck ghelt v dan, eel ionghelinck reijn, daer mede suuer ionste, dien ick tuwerst draghe om die chiere, die ghij mij hier toont certeijn. dien dronck ghelt $\mathrm{v}$ dan, eel ionghelinck reijn. ende daermede die voochdije mijnder hertsen pleijn tot uwen belieuen bij nachte, bij daghe. dien dronck ghelt $\mathrm{v}$ dan, eel ionghelinck reijn, daermede suuer ionste, dien ick tuwerts draghe. $\mathrm{nv}$ om huijssche vrolicheijt ick dit ghewaghe. hier cust zij hem en drinct.

VERBLENDE WILLE Soe meijsken, so spoelt te deghen v maghe, in sulcx niet te traghe wordij ghepresen. siet dat teefken lecken. (Cristenkercke 1273-84)

[HONEST SIMPLe FAITH This drink is for you, noble, pure youth, and with it pure goodwill, which I feel towards you because of the good cheer which you show me here, certainly. This drink is for you, noble, pure youth, and with it the guardianship of my whole heart, at your service, night and day. This drink is for you, noble, pure youth, and with it pure goodwill, which I feel towards you. 
Now for courteous joy I do this.

Here she kisses him and drinks.

BLINDED WILL So, lass, give your stomach a good rinse;

you are to be praised for not delaying in such matters.

Look how the bitch licks.]

In fact, most of the comedy of the sinnekens consists of either an ironic and dry reaction to the plot, such as 'Hurry up, get some fodder!' 'A sow is converting here', or criticisms of contemporary ills, as when Vleijschelijcke Sin [Carnal Desire] defends lecherous priests as being 'only human'. ${ }^{24}$

The extant but limited comic function of the sinnekens indicates that the Dutch playwrights were not averse to comedy and entertainment but that they saw it primarily as a useful means to underline the didactic message of the play. No comedy for comedy's sake operates in the Dutch spelen van sinne. The rhetoricians in the Low Countries did however distinguish between comical and serious plays. For instance, serious and comic plays appeared in separate categories at rhetoricians' competitions. One would therefore expect aspects commonly associated with comic plays to be relatively subdued in the serious rhetoricians' plays, as indeed they are, although the spelen van sinne and the sinnekens are not as a result boring. But their appeal probably lay more in their didactic character, which contemporary sources commended, and in their use of language, such as complicated rhyme schemes and quick alteration of short lines, which demonstrated the rhetorical skills of both playwright and actors. ${ }^{25}$

The Vice is on the whole more comical than the sinnekens. For instance, the dramatic and didactic functions of the Vice frequently enhance his comic function, as we have already noted. Comedy does not obliterate the didactic message of these characters and the Vice's comedy often has a moral purpose in these plays too. In the comical 'overheard aside' set-piece, the Vice commonly manages to reveal his own deceptive nature and the true nature of the character or action that forms the subject-matter of the aside, as in the following exchange about Treasure:

INCLINATION I may say to you she hath an ilfauoured sauour.

LUSTE What saiest thou?

INCLINATION I saye she is louing and of gentle behauior. (Trial 839-41) 
On occasion, the Vice weeps in an exaggerated comical manner to deceive the protagonist, as happens when Covetousness exclaims to Worldly Man, 'Oh sir, Oh good sir! Oh, oh, oh, my heart will break! / Oh, oh, for sorrow, God wot, I cannot speak' (Enough 700-1). A later stage direction gives a rough idea of the effectiveness of a theatrical spectacle: 'Let the Vice weep and howl and make great lamentation to the Worldly Man' (Enough after 707). Conversely, the Vice may also laugh at the misfortune of others; for example, in Like Will to Like Nichol Newfangle laughs at his deception of Philip Fleming and Hance (566) and again when Pierce Pickpurs and Cutbert Cutpurs are taken away to be hanged by Hankin Hangman (1168). Whereas instances such as these certainly have a didactic element to them, they also create moments of comedy. And while acknowledging the didactic importance of these comic instances, we should not underestimate the importance of the entertainment value of the Vice.

The Vice's important comic function includes his use of a wide variety of comic ploys, some of them unrelated to plot,demonstrating that his comic function is significant and elaborate. As the scope of this article does not allow a detailed discussion of the Vice's comic routines, I shall merely list a few examples to give an idea of their variety and nature. The Vice uses sexual innuendo, as when Infidelitie asks Mary Magdalen,

If that you can play vpon the recorder,

I haue as fayre a one as any is in this border,

Truely you haue not sene a more goodlie pipe,

It is so bigge that your hand can it not gripe.

(Mary Magdalen 841-4)

The Vice pretends to mishear things in Like Will to Like:

DEVIL I will exalt thee above the clouds-

NICHOL NEWFANGLE I will salt thee and hang thee in the shrouds.

(Like Will to Like 208-9)

The humour of the Vice is often verbal, with nonsense being especially prominent, as in the nonsense joke in Enough (1024-6) and the Vice's opening soliloquy in Grissell (3-54). But we also find instances of a more physical comedy, as when the Vice pretends to ride a (hobby-)horse at the beginning of Horestes. The appearance of Ambidexter ('Enter the Vice with an olde 
Capcase on his hed, an olde pail about his hips for harness, a Scummer and a potlid by his side and a rake on his shoulder', Cambises stage direction after 125 ) would presumably have produced at least a smile from most members of the audience. The Vice moreover wants to fight, usually with minor vice characters, and these scenes provide an opportunity for comedy and extensive theatrical stage action which the actors presumably seized to the full. The Vice is sometimes defeated; for example, Inclination is bridled by Just in Trial (420-91) and in Cambises Ambidexter is beaten first by Lob and Hob and later by Marian (stage directions after 812 and 833). This more physical comedy is not normally a feature encountered with the sinnekens. The Vice's range of comedy is therefore wider than that of the sinnekens and his comic function more prominent.

On the other hand in the English plays other characters can have an important comic element, approaching, or even exceeding, the comedy of the Vice. For instance, the minor vices in Respublica have their fair share of comedy. In Horestes Rusticus and Hodge, and Haultersycke and Hempstryng seem to be present mainly for comic value, which makes their comic function much more important than that of the Vice. But, I would stress, frequently, although by no means exclusively, the interaction between the Vice and these minor comic characters creates comedy. I have already shown how the exchanges between Avarice and Adulation in which the latter forgets and mishears the aliases of the Vice and other minor vices take on didactic as well as comic purposes. In Enough the first encounter between the minor vices and the Vice contains a lengthy struggle by the Vice to be accepted as their superior. Didactic to a degree, it emphasizes that "Covetous," sayeth the wise man, "is the root of all evil"' (Enough 434). But what is presumably more memorable for an audience is the resulting fight (Enough stage direction after 441) and the ironically obsequious behaviour of the minor vices, as when they exclaim in unison 'Oh worthy Prince Covetous, we humbly salute ye!' (471). This addition of comical characters indicates a stronger emphasis on the comic and entertainment aspects in the English plays vis-à-vis the Dutch plays.

Both the Vice and sinnekens therefore have a comic function but it is never as important for the sinnekens as it is for the Vice. Moreover, this difference, not limited to these dramatic types, indicates a fundamental difference between the two dramatic traditions more generally. The marked distinction between comical and serious plays in the Low Countries resulted in the muting of comedy in the spelen van sinne overall. The authors of the 
English moral interludes, on the other hand, did not attempt to divide the serious and the comic and incorporated distinctly farcical elements, such as the knockabout scene, into their moral plays. ${ }^{26}$ The (semi-)professional character of many interludes was probably responsible, at least partly, for their entertainment orientation. Two important aims for both playwrights and actors, often openly acknowledged in the prologues, were, first, to please their audiences and patrons and, second, not to offend their audiences and patrons. Although these plays moralize, the carrot is at least as important as the stick. As the prologue of Like Will to Like explains:

Herein as it were a glass see you may

The advancement of virtue, of vice the decay;

$\cdots$

And because divers men of divers minds be,

Some do matters of mirth and pastime require,

Other some are delighted with matters of gravity;

To please all men is our author's chief desire,

Wherefore mirth with measure to sadness is annexed,

Desiring that none here at our matter will be perplexed.

(Like Will to Like 17-30)

This difference between the two dramatic traditions overall reflects their use of the Vice and sinnekens: the Dutch playwrights were more interested in the didactic effect than the entertainment value of the sinnekens whereas the English playwrights were at least as concerned with the entertainment value as with the didactic effect of the Vice.

\section{Conceptual Function}

I have already pointed out that the names of the characters under discussion carry a didactic message but they also indicate a conceptual function. ${ }^{27}$ The Dutch plays tend to emphasize the personification of the sinnekens: they are eternal, general evils, often characterized through the blame-and/or-boastmotif, and they do not fear death. In the English plays, in contrast, the supposedly immortal and unchangeable Vice characters are susceptible to death; for instance, Courage in Tide is taken off to his execution at the end of the play. Although rare, the Vice can convert to virtue; thus Perverse Doctrine in New Custom has a change of heart and becomes Sincere Doctrine (888-918). 
The name Nichol Newfangle in Like Will to Like links this Vice to the other type-characters in the play, such as Pierce Pickpurs, and distinguishes him from the personifications, such as Honour. Occasionally, the Vice behaves more as a sinner than an instigator of sin. For example, Avarice in Respublica repeatedly shows his avarice but although he paves the way for the rapacious behaviour of other characters he does not engender avarice in these other characters. In the drama of the Low Countries none of this confusion between the sin and the sinner occurs; for example, Vreese voor Schande [Fear of Shame] is not in the least concerned about scandal, nor is Onbehoorlijcke Lust [Improper Lust] particularly lustful.

The Vice is sometimes emphatically internal, as when Infidelitie claims 'for in his heart I am euen now inuisible' (Mary Magdalen 1076), but usually the Vice appears as an external, physical being. In fact, Mary Magdalen and the same Infidelitie kiss and embrace (as in 309-14), revealing that there is nothing invisible about his relationship with her. When Poverty acknowledges his fall into sin, he does not blame his own bad impulses or evil concepts but rather 'evil company' (Poverty 924). Conversely, the sinnekens are usually identified as internal evil concepts rather than external agents; for example, Meest Elc [Most Individuals] is told that 'you are now bending under Deception and Trick: / you have internally imbibed their teaching' and the prodigal son complains that 'Evil Will advises me within my heart'. ${ }^{28}$ But the sinnekens are not consistently portrayed as immaterial and internal concepts: the sinnekens in Cristenkercke are physically assaulted, although offstage (2274-86 and stage directions after 2273 and 2274). Some sinnekens represent more external concepts, such as Bedrieghelic Waen [Deceptive Appearance] and Fraudelic Schijn [Fraudulent Impression]. But overall there is little or no emphasis on the physical and material presence of the sinnekens and this lack of emphasis may account, at least partially, for the relative lack of physical comedy associated with these characters. In fact, some of the sinnekens even seem to be invisible to their victims. Thus toward the end of Spiegel, after Katherina and the sinneken Vreese voor Schande [Fear of Shame] have interacted on several occasions, we encounter the following dialogue:

KATHERINA Wy sydy katijf?

VREESE VOOR SCHANDE En kendy my niet

So sidy blint geworden in Venus warande.

KATHERINA Ick en sach u niet.

(Spiegel 4226-8) 
[KATHERINA Who are you, wretch?

FEAR OF SHAME If you do not know me

you must have been blinded in Venus' bower.

KATHERINA I did not see you.]

This divergence in the conceptual presentation of the Vice and sinnekens has rather far-reaching effects. As a result of the Vice's characterization in more human terms, his name mainly contains his conceptual function; as we have already seen, the name enhances primarily the theatrical and metatheatrical appeal of the Vice and only secondarily his didactic and conceptual function. The sinnekens, on the other hand, are presented as eternal, general, and often all-knowing forces of evil, and their conceptual function is consequently more important than that of the Vice. The sinnekens' conceptual function, moreover, is not only important in itself but also augments their didactic and technical functions, though not their theatrical or metatheatrical appeal. Here, again, we note an important difference between the two dramatic traditions.

\section{Influence or Indepedence?}

What does this analysis of the functions of the Vice and sinnekens tell us about their interdependence or lack of it? Although the functions of these two sixteenth-century conventional dramatic types are remarkably similar, one distinction stands out: the English plays repeatedly give the impression that various functions serve mainly to enhance the theatricality, particularly through comedy, and the metatheatricality of the Vice. Thus, for example, the comments on contemporary reality allow for comedy and metatheatricality; their didactic content seems almost to be an excuse for verbosity and audience interaction rather than an end in itself. This quality ties in with the greater importance of the comic function of the Vice, and with the repeated emphasis on entertainment on the title-pages of the early modern editions where we find appraisals such as 'ful of plesant [or 'pleasant'] mirth' (Like Will to Like and Cambises). It does not reduce the overall didactic effect of the plays: the appeal of evil personifications reinforces a kind of manipulative authority over the spectators and makes the audience experience the attractive influence of the Vice, minor vices, and consequently of the concepts they represent.

Essentially, the English and Dutch playwrights used these characters for different reasons and achieved different effects. The English writers exploited 
the entertainment value of the Vice to the full, making the Vice a potent theatrical and metatheatrical dramatic type, whose structural or narrative functions are of lesser importance. The fact that most moral interludes were written for (semi-)professional troupes may account for this emphasis on entertainment as these troupes were dependent on the financial support and goodwill of their audiences and patrons. The greater use of interaction with the audience and the wider variety of verbal and physical comic routines also permitted the actors, and especially the actor playing the Vice, to exhibit their skills and talents. The Dutch playwrights, on the other hand, were not as eager to exploit the entertainment aspects of the sinnekens as the English authors were in respect of the Vice. Instead, the playrights emphasized the sinnekens' technical, didactic, and conceptual functions. This use of the sinnekens reflects the rhetoricians' interest in education and their relatively strict distinction between serious and comic plays. The latter ensured that comic elements, which the rhetoricians used extensively in their farces, were limited in the spelen van sinne and consequently that the entertainment aspect of the sinnekens was subdued. The former resulted in a greater didactic and conceptual load of the spelen van sinne and the sinnekens in particular. Yet the Dutch playwrights were perhaps most interested in the practical advantages these personifications of evil could bring to the play; hence, the particular importance of the sinnekens' technical function.

Despite the many similarities between the Vice and sinnekens as dramatic types, the divergent importance of their various functions indicates that they were used in different ways, for different reasons, and with different effects. The English Vice and Dutch sinnekens appear, consequently, to have developed independently and thus reflect inherent differences between the two dramatic traditions.

\section{Corpus of Cited Dutch and English Plays}

The Dutch plays and sinnekens under discussion are listed by date:

c 1500 Jan Smeeken, Mars en Venus; Hue Mars en Venus Tsaemen Bueleerden [How Mars and Venus Dallied Together] ${ }^{29}$

- Jolijt van Ooghen [Pleasure of Eyes]

- Ghepeijs van Minnen [Thoughts of Love]

Pre-1503 Colijn van Rijssele, Spiegel; De Spiegel der Minnen [The Mirror of Love $]^{30}$ 
- Vreese voor Schande [Fear of Shame]

- Begheerte van Hoocheden [Desire for Highness]

- Jalours Ghepeyns [Jealous Thoughts]

1485-c 1520 Anonymous, Antwerp Pyramus ende Thisbe; Pyramus ende Thisbe 31

- Bedrieghelic Waen [Deceptive Appearance]

- Fraudelic Schijn [Fraudulent Impression]

c 1512 Cornelis Everaert, Sanders Welvaren; Tspel van Een Sanders Welvaren [The Play of Another's Well-Being ${ }^{32}$

- Practyckeghen List [Cunning Trick]

- Suptyl Bedroch [Subtle Deception]

1500-25 Anonymous, Haarlem Piramus en Thisbe; Een Spel van Sinnen van de Historie van Piramus en Thisbe Genaempt de Sinnelijcke Genegentheijt [A Moral Play of the History of Pyramus and Thisbe Called the Sensual Inclination $]^{33}$

- Sinnelijcke Genegenheijt [Sensual Inclination]

- Hertelijcke Lust [Lust of the Heart]

1539 Anonymous, Caprijke (performed in Ghent) ${ }^{34}$

- Verdwaesde Iongheyt [Foolish Youth]

- Vieryghe Lust [Fiery Lust]

c 1540 Reynier Pouwelsz, Cristenkercke; Tspel van de Cristenkercke [The Play of the Christian Church ${ }^{35}$

- Verblinde Wille [Blinded Will]

- Hertnackich Herte [Obnoxious Heart]

1546 Cornelis Meeusz van Hout (probable), sMenschen Sin; Een Esbattement van sMenschen Sin en Verganckelijcke Schoonheit [A Play of Man's Desire and Fleeting Beauty] ${ }^{36}$

- Ghewoont [Custom]

- Manier [Manner]

1551 Jan van den Berghe, Wellustige Mensch; Het spel van Sinnen Genaempt den Wellustigen Mensch en sMenschen Crancheijt [A Moral Play Called the Voluptuous Man and Man's Illness] (performed in Antwerp) ${ }^{37}$

- Quaet Gelove [Evil Faith]

- Vleijschelijcke Sin [Carnal Desire] 
c 1564 Lauris Jansz, Meestal; Meestal Verjaecht Neering [Most People Chase Trade Away] ${ }^{38}$

- Welvaarts Benijdinge [Envy of Prosperity]

- Nerings Verdervinge [Ruin of Trade]

nd Jan Tomisz, Becooringe; Spel van die Becooringe des Duvels Hoe Hij Crijstus Becoorden [Play of the Temptation by the Devil, How He Tempted Christ $]^{39}$

- Ewige Haet [Eternal Hatred]

- Geveijnsde Hovaerdij [Fake Pride]

c 1559-c 1583 Lauris Jansz, Redelickheijt; Die Mensch Veracht die Redelickheijt [Man Despises Reason $]^{40}$

- Onbehoorlijcke Lust [Improper Lust]

- Blijnde Begeerte [Blind Desire]

1583 Robert Lawet, Zoone; De Verlooren Zoone [The Prodigal Son] ${ }^{41}$

- Quaden Wille [Evil Will]

- Sinnelick Ingheven [Sensual Inclination]

The English corpus comprises the following plays and Vices, also in order of date:

1547-53 R. Wever, Lusty Juventus; An Enterlude Called Lusty Juventus ${ }^{42}$

- Hypocrisy

1553 Nicholas Udall(?), Respublica; A Merry Interlude Entitled Respublica ${ }^{43}$

- Avarice

1550-62 Lewis Wager, Mary Magdalen; A New Enterlude ... Entreating of the Life and Repentaunce of Marie Magdalene ${ }^{44}$

- Infidelitie

1547-58 Anonymous, Poverty; A New Interlude of Impatient Poverty ${ }^{45}$

- Envy

1558-61 John Phillips, Grissell; The Commodye of Patient and Meek Grissell ${ }^{46}$ - Polliticke Perswasion

c 1560-69 Thomas Preston, Cambises; A Lamentable Tragedy Mixed Ful of Pleasant Mirth, Conteyning the Life of Cambises King of Percia ${ }^{47}$

- Ambidexter

1559-67 Anonymous, Apius and Virginia; A New Tragicall Comedie of Apius and Virginia ${ }^{48}$ 
- Haphazard

1562-8 Ulpian Fulwell, Like Will to Like; An Enterlude Intituled Like Wil to Like Quod the Deuel to the Colier 49

- Nichol Newfangle

c 1565-7 William Wager, Trial; A New and Mery Enterlude, Called the Triall of Treasure ${ }^{50}$

- Inclination

c 1567 John Pickering (?), Horestes; A Newe Enterlude of Vice Conteyning the History of Horestes ${ }^{51}$

- The Vyce (called both Courrage and Revenge in the play)

1559-70 William Wager, Enough; A comedy or Enterlude Intituled Inough Is as Good as a Feast ${ }^{52}$

- Covetousness

1550-73 Anonymous, New Custom; A New Enterlude ... Entituled New Custome ${ }^{53}$

- Peruerse Doctrine

before 1576 George Wapull, Tide; TheTyde Taryeth No Man () ${ }^{54}$

- Courage

\section{Notes}

This research is based on part of my doctoral thesis which was generously funded by the Arts and Humanities Research Council, and which benefited much from the insightful comments of my two supervisors, Elsa Strietman and Peter Happé.

1 The meaning of the terms are contested. The meanings 'desire' or 'inclination' are probably most relevant for the dramatic type of sinneken, whereas spelen van sinne probably meant 'plays with a moral'. The meaning and reference of Vice is also not easy to define; see, for instance, Peter Happé, ed., Tudor Interludes (Harmondsworth, 1972), 15, John D. Cox, The Devil and the Sacred in English Drama, 13501642 (Cambridge, 2000), 226, and Greg Walker, Plays of Persuasion: Drama and Politics at the Court of Henry VIII (Cambridge, 1991), 142.

2 Bernard Spivack, Shakespeare and the Allegory of Evil (New York, 1958) and W.M.H. Hummelen, De Sinnekens in het Rederijkersdrama (Groningen, 1958). See also Peter Happé, 'The Vice, 1350-1605: An Examination of the Nature and Development of a Stage Convention', $\mathrm{PhD}$ thesis (London University, 1966). 
3 These characters are usually labelled 'allegorical' but the evident correspondence between concept, fictional character, and his or her name leaves little room for 'oblique allegorical activity'; see Jon Whitman, Allegory: The Dynamics of an Ancient and Medieval Technique (Oxford, 1987), 6 .

4 See, for example, Alexandra F. Johnston, 'Traders and Playmakers: English Guildsmen and the Low Countries', Caroline Barron and Nigel Saul (eds), England and the Low Countries in the Late Middle Ages (Stroud, 1995), 99-114. King also seems to link the flowering of morality drama in late medieval East Anglia to relations with the continent; Pamela M. King, 'Morality Plays', Richard Beadle (ed.), The Cambridge Companion to Medieval English Theatre (Cambridge, 1994), 243-4.

5 W.H.M. Hummelen, 'The Dramatic Structure of the Dutch Morality', Dutch Crossing 22 (1984), 17. But whether 'vices' in his terminology refers to the minor vices or to the Vice is unclear.

6 Peter Happé and Wim Hüsken, “Sinnekens" and the Vice: Prolegomena', Comparative Drama 29 (1995), 248.

7 Peter Happé, 'Deceptions: “The Vice” of the Interludes and Iago', in Theta 8 (2009), 107-9, and Peter Happé, 'Laughter in Court: Four Tudor Comedies (1518-1585), from Skelton to Lyly', Tudor Theatre 6 (2002), 120, Cox, The Devil and the Sacred, 79, and Happé, 'The Vice, 1350-1605', 14-16.

8 If they were performed by small acting troupes they were probably taken on tour outside London. The dramatic supremacy of London is probably largely a misrepresentation due to the paucity of surviving play-texts associated with the provinces; see Suzanne Westfall, 'What Hath REED Wrought? REED and Patronage', Audrey Douglas and Sally-Beth MacLean (eds), REED in Review: Essays in Celebration of the First Twenty-Five Years (Toronto, 2006), 85.

9 See also W.M.H. Hummelen, 'Kamerspelers: Professionele Tegenspelers van de Rederijkers', Oud Holland 110 (1996), 117-134, and Herman Brinkman, 'Spelen om den Brode. Het Vroegste Beroepstoneel in de Nederlanden', Literatuur 17 (2000), 98-106.

10 See also E. van Autenboer, 'Een 'landjuweel' te Antwerpen in 1496?', Jaarboek De Fonteine 29 (1978-79), 125-49. For general information about the competitions, membership, structure, and charters of the chambers of rhetoric, see Anne-Laure Van Bruaene, Om Beters Wille: Rederijkerskamers en de Stedelijke Cultuur in de Zuidelijke Nederlanden (1400-1650) (Amsterdam, 2008), Arjan van Dixhoorn, Lustige Geesten: Rederijkers in de Noordelijke Nederlanden (1480-1650) (Amsterdam, 2009), and Samuel Mareel, Voor Vorst en Stad: Rederijkersliteratuur en Vorstenfeest in Vlaanderen en Brabant (1432-1561) (Amsterdam, 2010). 
11 Greg Walker, Plays of Persuasion, passim but especially 8-9, and The Politics of Performance in Early Renaissance Drama (Cambridge, 1998), passim but especially 66, 71.

12 Van Dixhoorn, Lustige Geesten, passim but especially chapter 5; 'Ontfangen ende leeren den wech der salicheden, ende den sin des redelicx verstants' (222). Also Arjan van Dixhoorn, 'Writing Poetry as Intellectual Training. Chambers of Rhetoric and the Development of Vernacular Intellectual Life in the Low Countries between 1480 and 1600', Koen Goudriaan, Jaap van Moolenbroek, and Ad Tervoort (eds), Education and Learning in The Netherlands, 1400-1600: Essays in Honour of Hilde de Ridder-Symoens (Leiden, 2004), 201-22; 'der kameren aller eerste instellingen: die zalmen bevinden als ghemene land taals scholen voor allen bejaarden kunstlievenden menschen tot oeffening van alle vermakelijcke ende land-nutte wetenschap opgerecht te zijn' (205); the translation is by van Dixhoorn.

13 Hummelen, Sinnekens.

14 The only untainted protagonists to be tempted by the sinnekens are Mensche (Man) in Caprijke and Mensch (Man) in Redelickheijt. In Becooringe the sinnekens do not attempt to face Jesus themselves, but instead influence the devil who is sent to tempt him.

15 Elsa Strietman introduces the term exacerbators in 'The Verbal Made Visual: The Allegorization of Moral Corruption and Political Debate in the Plays of Lauris Jansz. of Haarlem', European Medieval Drama 5 (2001), 188-9.

16 This happens in Poverty, Lusty Juventus, Respublica, Grissell, and Enough. Respublica is an exception because, although she is deceived by the Vice and the vices, she is never corrupted by them in the way that, for example, Worldly Man is in Enough. In the dual-protagonist plays, namely Trial and Enough, the virtuous protagonist is impervious to the Vice's wiles.

17 The only sinnekens who do not boast of their general influence occur in plays in which the sinnekens exert no influence over the protagonist and plot development: Mars en Venus, Antwerp Pyramus en Thisbe, and Meestal.

18 The eternal aspect is stressed in Cristenkercke, Wellustige Mensch, Becooringe, Redelickheijt, and Zoone. For beschuldigingsmotief, see Hummelen, Sinnekens, 92-4.

19 For the sub specie aeternitatis aspect of the scenes-apart of sinnekens see Hummelen, 'Dramatic Structure', 17.

20 No one knows how widespread the use of name tags was - there are a few other references - but if and when they were used, they must have underlined the conceptual and didactic function even more; see also Hummelen, Sinnekens, 58-9.

21 'Eewige haet quaet / u valsche raet gaet in allen rijcken' (Becooringe 29-30).

22 'Laet u Dienen met het sweet der armen / acht niet haer carmen' (Becooringe 1152-3). 
23 The exception is Becooringe where the main comical character is the hapless devil.

24 Suptyl Bedroch. 'Spoetge, haelt draf!' Practyckeghen List 'Hier bekeert een zeughe' (Welvaren 710) and 'priesters sijn oock menschen' (Wellustige Mensch 229).

25 For example, the accounts of Oudenaarde for 1553-4 record a compensation to 'all the rhetoricians of the chamber of rhetoric of Pax Vobis of this very town, because they took pains and laboured much for the teaching, instruction and moral education of all people, having shown, with figures and rhetorically, the play of the vineyard and the stoning of Naboth the Israelite' ('De ghemeene retorichienen van de camer van der retorijcken van Pax Vobis binnen deser stede, van dat zij groot last ende debvoir ghedaen hebben, tot leeringhe, onderwijsinghe ende ghestichtichede van alle menschen, figuerlic in retorijcke vertoocht hebben tspel van den wijngaert ende steenijnghe van Naboth den ijsraelijt'); B.A.M. Ramakers, Spelen en Figuren: Toneelkunst en Processiecultuur in Oudenaarde tussen Middeleeuwen en Moderne Tijd (Amsterdam, 1996), 157.

26 See also Jean-Paul Debax, 'Farce and Farcical Elements in the English Interludes, or: How the Vice Beat the Farce', Ludus: Medieval and Early Renaissance Theatre and Drama 6 (2002), 71-84.

27 The only Vice with a name that is not properly conceptual in my corpus is Nichol Newfangle in Like Will to Like.

28 'Onder Bedroch ende List zyt ghy hu bughelic./ Huer leerynghe zughelic hebt ghy inwendich ghesoghen' (Welvaren 599-600) and 'den Quaden Wille raet my int herte binnen' (Zoone I.628).

29 Ingrid van de Wijer (ed.), 'Hue Mars en Venus Tsaemen Bueleerden. Rederijkersspel Toegeschreven aan Jan Smeeken, uitgegeven naar Ms. II 368 Kon. Bibl. Brussel', Karel Porteman (ed.), Uut Goeder Jonsten. Studies Aangeboden aan Prof. Dr. L. Roose Naar Aanleiding van Zijn Emeritaat (Leuven, 1984), 33-91. For the date, see also Martin Gosman and Rina Walthaus (eds), European Theatre, 1470-1600: Traditions and Transformations (Groningen, 1996), 230.

30 M.W. Immink (ed.), De Spiegel der Minnen door Colijn van Rijssele (Utrecht, 1913). For the authorship and date, see J.E. van Gijsen, Liefde, Kosmos en Verbeelding: Mens-en Wereldbeeld in Colijn van Rijsseles 'Spiegel der Minnen' (Groningen, 1989), 20-1.

31 G.A. Van Es (ed.), Piramus en Thisbe: Twee Rederijkersspelen uit de Zestiende Eeuw (Zwolle, 1965). The editor ascribes the play to Matthijs de Castelein and dates the play to c 1515 but there is no good evidence to support these claims. I have followed A.C.M. van Herk who, in private communication, suggested Colard Mansion's edition of Ovide moralisé in 1484 as terminus post quem and the print of c 1520 as 
terminus ante quem. She also suggests that the play originated in Bruges, but the earliest surviving print is from Antwerp.

32 W.N.M. Hüsken (ed.), De Spelen van Cornelis Everaert, 2 vols (Hilversum, 2005).

33 Van Es, Piramus en Thisbe. The editor gives a more precise date, but as this is based on circumstantial evidence I have again followed van Herk (private communication). The play is probably from Amsterdam, but survives in a Haarlem compilation.

34 B.H. Erné and L.M. van Dis (eds), De Gentse Spelen van 1539, 2 vols (The Hague, 1982).

35 G.A. Brands (ed.), Tspel van de Cristenkercke (Utrecht, 1923). Hüsken, however, claims that it may have been written well before 1540; Wim Hüsken, "Heresy" in the Plays of the Dutch Rhetoricians', Elsa Strietman and Peter Happé (eds), Urban Theatre in the Low Countries, 1400-1625 (Turnhout, 2006), 111, n.23.

36 Medewerkers van het Nederlands Instituut der Rijksuniversiteit Groningen (eds), Een Esbattement van sMenschen Sin en Verganckelijcke Schoonheit (Zwolle, 1967). For the date and authorship, see Elsa Strietman (ed.), Een Esbattement van sMenschen Sin en Verganckelijcke Schoonheit: Man's Desire and Fleeting Beauty, trans. Robert Potter and Elsa Strietman (Leeds, 1994), viii.

37 C. Kruyskamp (ed.), Dichten en Spelen van Jan van den Berghe (The Hague, 1950). The text, with probably only some slight changes, survives in a manuscript compilation of c 1600; see Kruyskamp, xi-xii, xxi.

38 N. van der Laan (ed.), Noordnederlandse Rederijkersspelen (Brussel, 1941). I have cited Hummelen's short title rather than the long descriptive heading in the manuscript; W.M.H. Hummelen, Repertorium van het Rederijkersdrama, 1500-ca. 1620 (Assen, 1968), 1 OD 5.

39 W.N.M. Hüsken, B.A.M. Ramakers, and F.A.M. Schaars (eds), Trou Moet Blijcken, Bronnenuitgave van de Boeken der Haarlemse Rederijkerskamer 'de Pellicanisten', 8 vols (Assen, 1992-98), vol. 6.

40 Ibid, vol. 5. I have used Hummelen's short title instead of the long descriptive heading of the manuscript; Hummelen, Repertorium, $1 \mathrm{OE} 10$. The play is not dated but the dated plays by Lauris Jansz span the period 1559-1583.

41 Egidius Gerardus Antonius Galama (ed.), Twee Zestiende-Eeuwse Spelen van de Verlooren Zoone door Robert Lawet (Utrecht, 1941). I have used Hummelen's short title as part 1 and part 2 carry slightly different headings; Hummelen, Repertorium, $1 \mathrm{M} 7$.

42 Unless otherwise specified, the dates are those found in Darryll Grantley, English Dramatic Interludes, 1300-1580: A Reference Guide (Cambridge, 2004). The edition used is J.A.B. Somerset (ed.), Four Tudor Interludes (London, 1974). 
43 Edgar T. Schell and J.D. Shuchter (eds), English Moraltiy [sic] Plays and Moral Interludes (New York, 1969).

44 P.W. White (ed.), Reformation Biblical Drama in England: An Old-Spelling Critical Edition (New York, 1992). Grantley dates the play 1550-1566 but P.W. White claims that Lewis Wager died in 1562. This date is supported in Mark Eccles, 'William Wager and His Plays', English Language Notes 18 (1981), 258.

45 Leonard Tennenhouse (ed.), The Tudor Interludes 'Nice Wanton' and 'Impatient Poverty' (New York, 1984).

46 The Malone Society Reprints (London, 1909) in Chadwyck-Healey Database in Literature Online, http://lion.chadwyck.co.uk, henceforth Chadwyck-Healey.

47 Robert Carl Johnson (ed.), A Critical Edition of Thomas Preston's 'Cambises' (Salzburg, 1975).

48 Happé, Tudor Interludes.

49 Somerset, Interludes.

50 Chadwyck-Healey; Grantley merely mentions the date of publication (1567), but the biographic details in Chadwyck-Healey claim that William Wager flourished from 1565 until 1569. For the authorship of William Wager, see also Eccles, 'William Wager'.

51 Marie Axton (ed.), Three Tudor Classical Interludes: 'Thersites', 'Jacke Jugeler', 'Horestes' (Cambridge, 1982). Some evidence suggests that the play may have been performed in the winter of 1567-1568 and the play was printed in 1567; see Ibid, 29, and Grantley, English Dramatic Interludes, 1300-1580.

52 Schell and Shuchter. The title is taken from Chadwyck-Healey; for the authorship of William Wager, see also Eccles, 'William Wager'.

53 Chadwyck-Healey.

54 Schell and Shuchter, English Moraltiy [sic] Plays and Moral Interludes. The title is taken from Chadwyck-Healey. 
